\title{
Investigating the correlation between body temperature and body mass index: a meta-analysis
}

\author{
Sajjad Rahimi Pordanjani ${ }^{1}$, Mohammad-Javad Jafari², Mostafa Pouyakian ${ }^{3}$, Abbas Shafikhani ${ }^{4}$, Ali Akbar \\ Shafikhani ${ }^{5}$
}

${ }^{1}$ PhD Student in Epidemiology, School of Public Health and Safety, Shahid Beheshti University of Medical Sciences, Tehran, Iran.

${ }^{2}$ Professor, Safety Promotion and Injury Prevention Research Center, Shahid Beheshti University of Medical Sciences, Tehran, Iran

${ }^{3}$ Assistant Professor of Occupational Health and Safety Engineering, School of Public Health and Safety, Shahid Beheshti University of Medical Sciences, Tehran

${ }^{4}$ Director of Planning and Project Control, Niroumoharekeh Machine Tools Co., Gazvin, Iran

${ }^{5} \mathrm{PhD}$ Student of Occupational Health and Safety Engineering, School of Public Health and Safety, Shahid Beheshti University of Medical Sciences, Tehran

Type of article: Meta-analysis

\begin{abstract}
Background: The relationship between body temperature and body mass index is controversial.

Objective: The purpose of this study was to determine the relationship between these two variables in various studies.

Methods: A systematic review was conducted in Google Scholar, PubMed, Scopus, ProQuest, Web of Science, and Elsevier databases. Studies were searched and collected from May 9, 1980 to April 19, 2019. The preliminary steps before data extraction included the selection of the study and the qualitative evaluation of the studies. Mesh database was used for all search keywords. The quality of studies was assessed according to 'Cochrane's checklist, related articles and literature. This led to the inclusion of five articles. Next, all the effect sizes were converted into correlations; then, the relationship between temperature and Body Mass Index was estimated. An appropriate model was selected according to 'Cochran's Q Test. Sensitivity analysis was used to assess the stability and heterogeneity of the findings. All analyses were performed through Comprehensive CMA software, version 3.

Results: Overall, the analysis showed a positive correlation between body temperature and body mass index at a $95 \%$ confidence interval ( $\mathrm{r}=0.5895 \%$ CI: $0.05-0.85)$. The effect of the age variable was significant in explaining inter-group variance $\left(\mathrm{p}<0.05, \mathrm{R}^{2}=0.43\right)$. For men, a positive and significant relationship was found between changes in body temperature and body mass index ( $\mathrm{r}=0.15895 \% \mathrm{CI}: 0.11-0.19, \mathrm{p} \leq 0.05)$. However, there was no significant relationship for women ( $\mathrm{r}=0.32,95 \% \mathrm{CI}:-0.1-0.64, \mathrm{p}=0.13)$.

Conclusion: A relationship between body temperature and BMI was found in the total population and men. The lack of a significant relationship in women may be due to sudden and severe secretion of luteinizing hormone (LH) in the menstrual cycle.

Keywords: Meta-analysis, Body Temperature, Body Mass Index, Correlation
\end{abstract}

Abbreviations / Acronyms:

BMI: Body Mass Index; LH: luteinizing Hormone; PRISMA: Preferred Reporting Items for Systematic Reviews and Meta-Analyses

\section{Corresponding author:}

Ali Akbar Shafikhani, Department of Occupational Health and Safety Engineering, School of Public Health and Safety, Shahid Beheshti University of Medical Sciences, Tehran, Iran.

Tel: +982833790620-30, E-mail: ali.shafikhani@yahoo.com

Received: April 14, 2020, Accepted: August 11, 2020, Published: September 2020

iThenticate screening: August 11, 2020, English editing: August 30, 2020, Quality control: September 04, 2020

(C) 2020 The Authors. This is an open access article under the terms of the Creative Commons Attribution-NonCommercialNoDerivs License, which permits use and distribution in any medium, provided the original work is properly cited, the use is non-commercial and no modifications or adaptations are made. 
Note:

This study has followed the Preferred Reporting Items for Systematic Reviews and Meta-Analyses: The PRISMA Statement (http://www.prisma-statement.org). PRISMA is an evidence-based minimum set of items for reporting in systematic reviews and meta-analyses. PRISMA focuses on the reporting of reviews evaluating randomized trials, but can also be used as a basis for reporting systematic reviews of other types of research, particularly evaluations of interventions.

\section{Introduction}

The relationship between body temperature changes and its effects on health has gained increasing attention in recent years $(1,2)$. Body temperature is controlled by the thermoregulation centre in the anterior hypothalamus and is the result of a complex balance between metabolic processes, muscle activities, and possibly microbiome $(3,4)$. To maintain a proper function of the body, body temperature must be kept in a specific range $(5,6)$ to maintain a suitable metabolic range. Various factors can affect body temperature based on physiology (gender, age, and menstruation) and pathology (infection, inflammation, and neoplasia) $(7,8)$.

Several studies have revealed a contradictory association between body mass index (BMI) and obesity. Some studies have demonstrated a positive relationship between BMI and body temperature (9-11); in others, however, this was not the case (12-14). Most of these studies had a smaller sample size because they measured body temperature using pill-sized sensors. This method is not readily applicable to large samples $(10,12)$. Because of the so-called contradiction, it is necessary to collect all these contradictory effects. Hence, this study set to determine the relationship between body temperature and BMI in various studies. In this regard, the meta-analysis method was employed to balance and adjust the weight of studies in determining the average effect size.

\section{Material and Methods}

\subsection{Search strategy and study criteria}

The present study is a meta-analysis. A systematic search was performed across Google Scholar, PubMed, Scopus, ProQuest, Web of Science, and Elsevier. The data were updated on April 19, 2019. Mesh database was used for all search keywords. In the case of PubMed, for example, the search strategy was "body temperature « [mesh] AND "obesity" [mesh] OR" body mass index" [mesh]. To cover all the related studies, we also considered search-related references. Some studies have shown that the temperature measurement method is not significant in the outcome (15-17). This led to the entry of different methods of temperature measurement to the study. Animal studies, repetitive studies, and studies that measured other relationships were also excluded. Since the aim of the study was to find a relationship between temperature changes and metabolic effects, articles emphasizing long-term effects were omitted.

\subsection{Study selection}

The title and abstract of the articles were entered into Endnote software, and duplicates were removed. All titles and abstracts were reviewed by the researcher to eliminate unrelated items. The full text of qualified studies was downloaded and read. The researchers compared the results and reached a consensus to enter the qualified articles into a systematic review (Figure 1).

\subsection{Quality Assessment}

The quality of studies was assessed according to 'Cochrane's checklist (18), related articles and literature $(19,20)$, and based on the following criteria including study design, sample size, statistical methods, temperature measurement, intervening variables, and environmental factors. However, the studies in this field were significantly different in terms of common indices.

\subsection{Study extraction and publication bias}

The authors independently extracted the data using a standard checklist. After quality assessment, the articles that met the inclusion criteria were included in the study. The collected data comprised of the title, author, publication year, conclusion, study design, and place of study. The effect sizes estimate was expressed as a correlation. Finally, the Egger test was employed to determine publication bias. 


\subsection{Statistical analysis}

In the next step, statistical analysis was performed. For this purpose, all selected studies were analyzed. The statistical analysis consisted of two steps. First, all the estimated effect sizes were converted to correlations. Second, the mean of the estimated effect sizes was approximated using meta-analysis.

\subsubsection{Step one}

The correlation was considered a common index. Then, mean, frequency, and other indices were converted to correlations. For example, to convert $d$ index to $r$ (correlation), equations 1, 2, and 3 were adopted (21) as follows:

$$
\begin{aligned}
& \text { Equation 1) } \quad \mathrm{r}=\mathrm{d} /\left(\mathrm{d}^{2}+\alpha\right)^{1 / 2} \\
& \text { Equation 2) } \quad \alpha=\left(\mathrm{n}_{1}+\mathrm{n}_{2}\right)^{2} / \mathrm{n}_{1} \mathrm{n}_{2}
\end{aligned}
$$

Variance $r$ in this method is calculated according to Eq. 3:

\subsubsection{Step two}

$$
\text { Equation 3) } \quad V_{r}=a^{2} V_{d} /\left(d^{2}+a\right)^{3}
$$

The average effect size of five selected studies was estimated. Then, the appropriate model was selected according to 'Cochran's Q Test, from the two models (the fixed and random effects models). Sensitivity analysis was employed to assess the stability and heterogeneity of the findings. All analyses were performed using Microsoft Excel 2017 and Comprehensive Meta-Analysis (CMA) software, version 3.

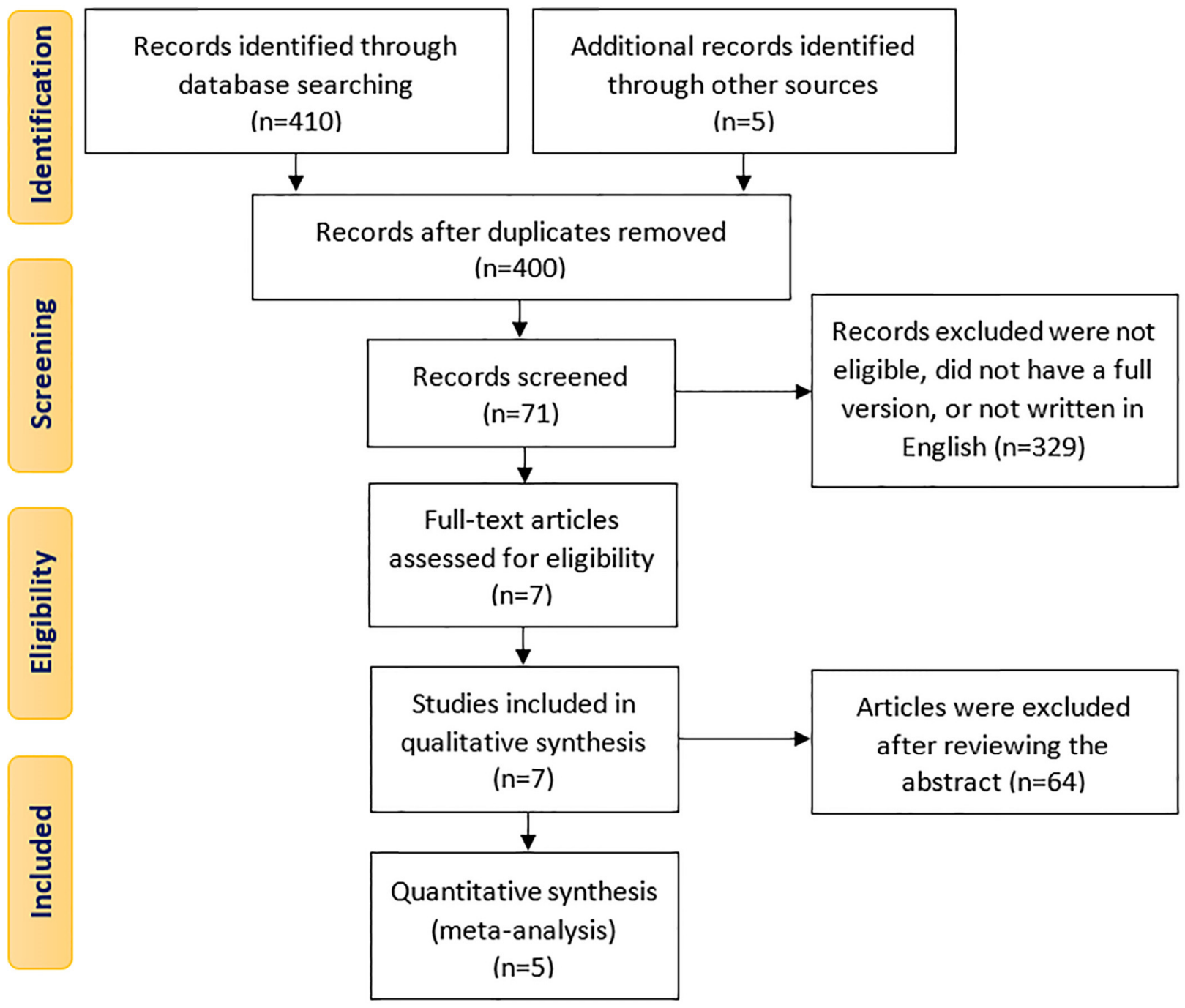

Figure 1. Flowchart of information in different phases of the systematic review (PRISMA 2009 Flow Diagram) 


\section{Results}

\subsection{General findings}

According to Figure 1, 400 articles were included in the initial search. After reviewing the article titles, 329 studies were found not eligible, and 64 were excluded after reviewing their abstracts. Finally, seven studies were included in the meta-analysis. Among the seven studies, only five studies had the inclusion criteria for meta-analysis. Figure 1 shows the flowchart of information at different steps of the meta-analysis. The characteristics of the selected articles are given in Table 1. Figure 2 shows the Forest Plot for a general analysis of the relationship between body temperature and BMI. Due to the rejection of the null hypothesis of the 'Cochran's Q Test, the random-effects model was adopted for analysis $(\mathrm{p}<0.05$, Q-VALUE $=312.98$, DF $(\mathrm{Q})=4)$. A positive relationship was observed between body temperature changes and BMI ( $\mathrm{p}=0.033)(0.58,95 \% \mathrm{CI}$ : 0.05 to 0.85$)$ (Figure 2$)$. The genderdisaggregated forest plot for men and women are presented in Figures 3 and 4, respectively. After calculating the average effect size for men, a positive and significant relationship was observed between body temperature changes and BMI $(\mathrm{p}<0.05)(0.158,95 \%$ CI: 0.11 to 0.19$)$. However, no significant relationship was observed between body temperature changes and BMI for women $(\mathrm{p}=0.137)(0.32,95 \% \mathrm{CI}$ : -0.10 to 0.64$)$.

\subsection{The review results of publication bias and other biases}

Egger regression test was used to evaluate the publication bias. Based on p-value $>0.05$, the hypothesis of the Egger regression test is accepted (Table 2).

Table 1. The characteristics of articles in the meta-analysis

\begin{tabular}{|c|c|c|c|c|c|c|c|}
\hline Code & $\begin{array}{l}\text { Publication } \\
\text { year }\end{array}$ & Author & Country & $\begin{array}{l}\text { Sample } \\
\text { size }\end{array}$ & $\begin{array}{l}\text { Type of } \\
\text { study }\end{array}$ & Gender & $\begin{array}{l}\text { Temperature } \\
\text { measurement }\end{array}$ \\
\hline 1 & 2019 & $\begin{array}{l}\text { Vollenweider } \\
\text { (22) }\end{array}$ & Switzerland & 4224 & Prospective & $\begin{array}{l}\text { Male (2032), } \\
\text { Premenstrual } \\
\text { women (631), } \\
\text { Postmenopausal } \\
\text { women (1561) }\end{array}$ & $\begin{array}{l}\text { Tympanic } \\
\text { membrane }\end{array}$ \\
\hline 2 & 2012 & $\begin{array}{l}\text { Linsenmeier } \\
\text { (23) }\end{array}$ & USA & 24 & $\begin{array}{l}\text { Cross- } \\
\text { sectional }\end{array}$ & $\begin{array}{l}\text { Male (12), Female } \\
\text { (12) }\end{array}$ & $\begin{array}{l}\text { Core } \\
\text { Temperature }\end{array}$ \\
\hline 3 & 2011 & $\begin{array}{l}\text { Yanovski } \\
\text { (24) }\end{array}$ & USA & $\begin{array}{l}\text { Non- } \\
\text { obese } \\
(35), \\
\text { Obese } \\
(46)\end{array}$ & $\begin{array}{l}\text { Cross- } \\
\text { sectional }\end{array}$ & $\begin{array}{l}\text { Non-obese } \\
\text { (Female: 19, Male } \\
\text { 16); Obese } \\
\text { (Female: } 34 \text {, Male } \\
\text { 12) }\end{array}$ & $\begin{array}{l}\text { Temperature- } \\
\text { sensing } \\
\text { capsule }\end{array}$ \\
\hline 4 & 1998 & $\operatorname{Kim}(25)$ & USA & 219 & $\begin{array}{l}\text { Cross- } \\
\text { sectional }\end{array}$ & $\begin{array}{l}\text { Male (78), Female } \\
(141)\end{array}$ & $\begin{array}{l}\text { Infrared } \\
\text { tympanic } \\
\text { thermometry } \\
\text { (ITT), } \\
\text { Tympanic } \\
\text { membrane }\end{array}$ \\
\hline 5 & 1989 & Adam (14) & $\begin{array}{l}\text { University of } \\
\text { California, } \\
\text { Los Angeles } \\
\text { (USA) }\end{array}$ & 60 & $\begin{array}{l}\text { Cross- } \\
\text { sectional }\end{array}$ & $\begin{array}{l}\text { Female (42), Male } \\
(18)\end{array}$ & $\begin{array}{l}\text { Oral } \\
\text { temperature }\end{array}$ \\
\hline
\end{tabular}

Table 2. The results of Egger regression in meta-analysis

\begin{tabular}{|l|l|l|l|l|l|l|}
\hline Intercept & Standard error & $95 \%$ lower limit & $95 \%$ upper limit & t-value & $\mathrm{df}$ & $\mathrm{p}$-value \\
\hline 6.66 & 5.86 & 12.06 & 25.38 & 1.1 & 3 & 0.33 \\
\hline
\end{tabular}




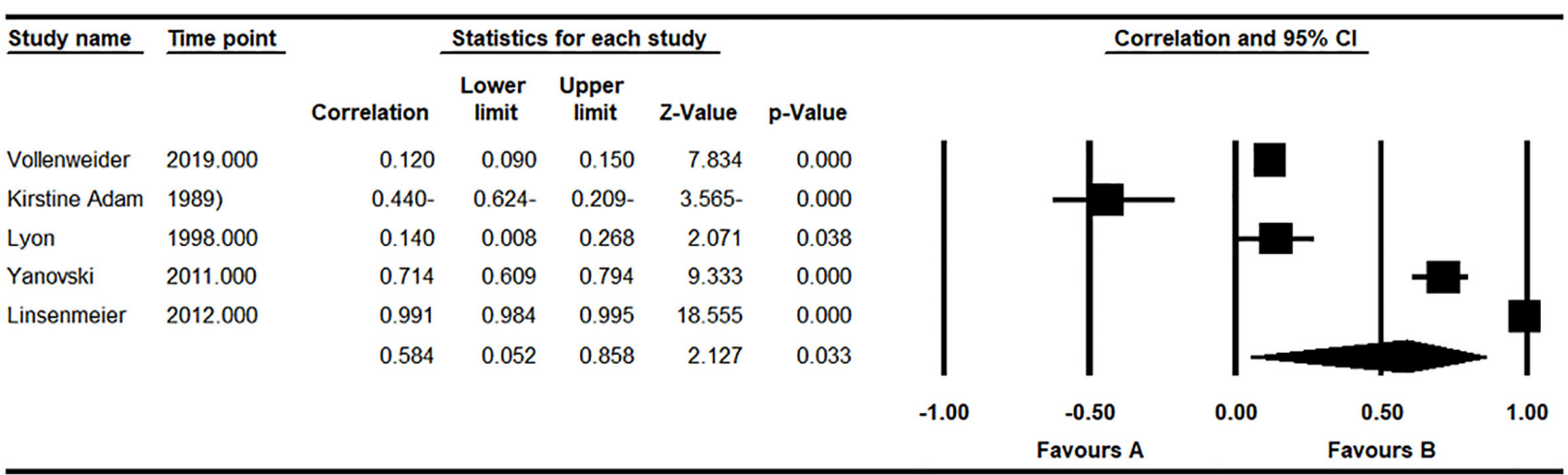

Figure 2. Forest plot for a general analysis of the relationship between body temperature and BMI

\begin{tabular}{|c|c|c|c|c|c|c|c|c|c|c|}
\hline \multirow[t]{2}{*}{ Study name } & \multirow[t]{2}{*}{ Time point } & \multirow[b]{2}{*}{ Correlation } & \multicolumn{3}{|c|}{ Statistics for each study } & \multirow[b]{2}{*}{ p-Value } & & \multicolumn{2}{|c|}{ Correlation and $95 \% \mathrm{Cl}$} & \\
\hline & & & $\begin{array}{l}\text { Lower } \\
\text { limit }\end{array}$ & $\begin{array}{c}\text { Upper } \\
\text { limit }\end{array}$ & Z-Value & & & & & \\
\hline Vollenweider & 2019.000 & 0.157 & 0.114 & 0.199 & 7.131 & 0.000 & & & 1 & \\
\hline Kirstine Adam & 1989) & 0.240 & 0.838 & 0.255 & $0.948-$ & 0.343 & & & & \\
\hline Lyon & 1998.000 & 0.240 & 0.018 & 0.439 & 2.120 & 0.034 & & & & \\
\hline Linsenmeier & 2012.000 & 0.988 . & 0.985 & 0.924 & $9.840-$ & 0.000 & & & & \\
\hline \multirow[t]{3}{*}{ Yanovski } & 2011.000 & 0.884 & 0.788 & 0.922 & 8.758 & 0.000 & & & & \\
\hline & & 0.158 & 0.117 & 0.199 & 7.458 & 0.000 & & & & \\
\hline & & & & & & & -1.00 & $\begin{array}{c}-0.50 \\
\text { Favours A }\end{array}$ & $\begin{array}{c}0.50 \\
\text { Favours B }\end{array}$ & 1.00 \\
\hline
\end{tabular}

Figure 3. Gender-disaggregated Forest Plot for men

\begin{tabular}{|c|c|c|c|c|c|c|c|c|c|c|c|}
\hline \multirow[t]{2}{*}{ Study name } & \multirow[t]{2}{*}{ Time point } & \multicolumn{5}{|c|}{ Statistics for each study } & \multicolumn{5}{|c|}{ Correlation and $95 \% \mathrm{Cl}$} \\
\hline & & Correlation & $\begin{array}{c}\text { Lower } \\
\text { limit }\end{array}$ & $\begin{array}{c}\text { Upper } \\
\text { limit }\end{array}$ & Z-Value & p-Value & & & & & \\
\hline Vollenweider & 2019.000 & 0.080 & 0.031 & 0.129 & 3.164 & 0.002 & & & & & \\
\hline Kirstine Adam & 1989) & 0.230 & 0.499 & 0.079 & $1.463-$ & 0.144 & & & & & \\
\hline Lyon & 1998.000 & 0.370 & 0.218 & 0.504 & 4.563 & 0.000 & & & & & \\
\hline Linsenmeier & 2012.000 & 0.064 & 0.463 & 0.557 & 0.222 & 0.825 & & & & & \\
\hline \multirow[t]{3}{*}{ Yanovski } & 2011.000 & 0.862 & 0.786 & 0.912 & 10.628 & 0.000 & & & & & \\
\hline & & 0.322 & $0.106-$ & 0.649 & 1.486 & 0.137 & & & & & \\
\hline & & & & & & & -1.00 & $\begin{array}{c}-0.50 \\
\text { Favours A }\end{array}$ & 0.00 & $\begin{array}{c}0.50 \\
\text { Favours B }\end{array}$ & 1.00 \\
\hline
\end{tabular}

Figure 4. Gender-disaggregated Forest Plot for women

\subsection{Calculation of I-SQUARE and R-SQUARE}

The results of the 'Cochran's Q Test showed that the between-study variance was about 98\% (98.98 = I-SQUARE). An analysis was performed to explain the between-study variance regarding the age variable. The results of the meta-regression test are shown in Figure 5. The results of the moderator variable (age) in explaining intergroup variance are presented in Tables 3 and 4 . In the slope line, the effect of the age variable is significant in explaining the intergroup variance $(p<0.001)$, and the extent of this effect is $R^{2}=0.43$.

Table 3. Explanatory variable results (age) for the intergroup variance

\begin{tabular}{|l|l|l|l|l|l|l|}
\hline Variable & Point estimate & Standard error & Lower limit & Upper limit & z-value & p-value \\
\hline Slope & -0.0037 & 0.0028 & -0.049 & 0.031 & 13.03 & 0 \\
\hline Intercept & 2.32 & 0.16 & 1.99 & 2.64 & 13.93 & 0 \\
\hline Tau_squared & 0.66 & & & & & \\
\hline
\end{tabular}


Table 4. Explanatory variable results (age) for intergroup variance

\begin{tabular}{|l|l|l|l|l|}
\hline Variable & $\mathrm{Q}$ & $\mathrm{df}$ & $\mathrm{p}$-value & \\
\hline Model & 169.88 & 1 & 0 & \\
\hline Residual & 223.0049 & 3 & 0 & \\
\hline Total & 392.88 & 4 & 0 & \\
\hline
\end{tabular}

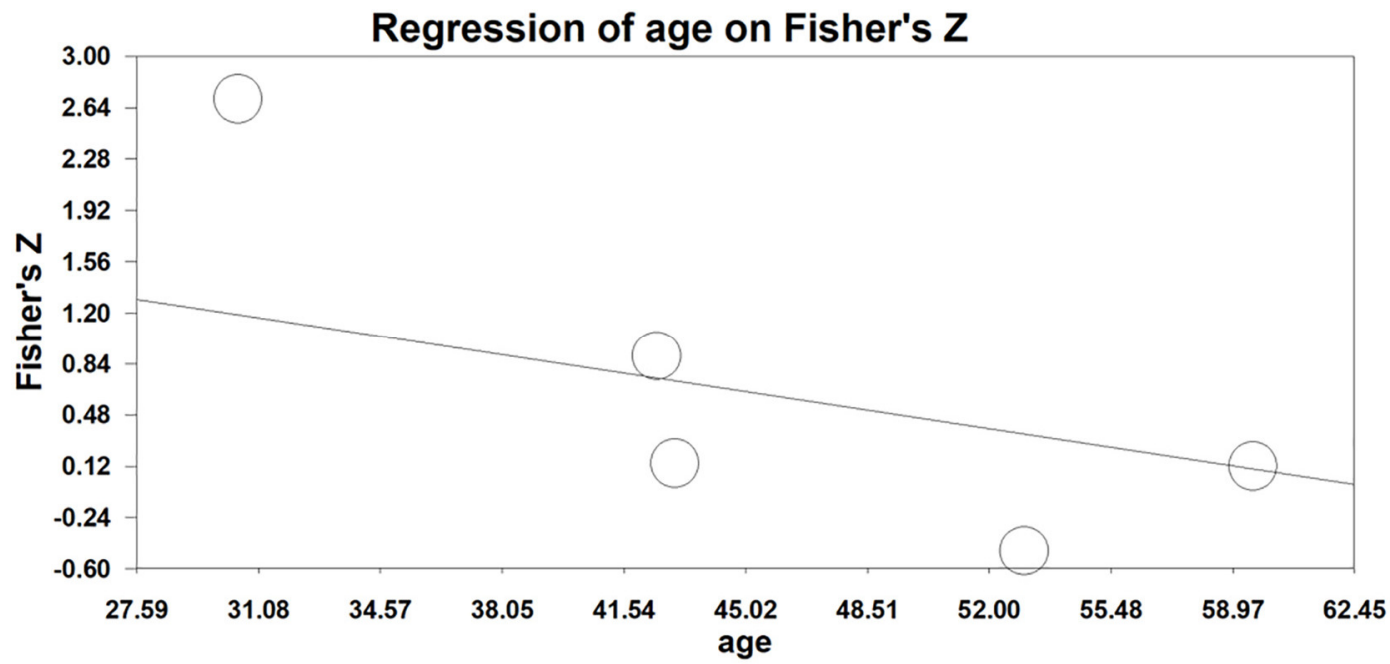

Figure 5. Meta-regression test results about between-study variance explanation

\section{Discussion}

The present study is the first meta-analysis research to examine the correlation between body temperature and BMI. The findings showed that the correlation between these two indices was positive and significant. The relationship between body temperature and BMI has been reported in various studies. Some researchers have reported a positive relationship between these two factors (9-11) and others have reported conflicting reports (12-14). This metaanalysis has been designed to answer conflicting evidence. As there have not been many studies in this area, the researchers were obliged to include studies with a smaller sample size in the meta-analysis to compensate for the relatively low power of these studies in explaining the average effect size. Hence, in the first stage, all the estimated effects were converted into correlation. In the second step, the estimated average effects were assessed through meta-analysis. Then, the average effect size was calculated according to the described methods. The results showed a positive and significant relationship between these two indices. In explaining the causality of this issue, there is a direct and significant relationship between body fat percentage and core body temperature. Thicker subcutaneous fat acts as an insulating layer between the skin surface the and deep tissues, especially in the extremities, abdomen, and trunk. This fat layer theoretically reduces heat transfer through conduction from the muscles to the surface of the skin. However, an increase in body surface area, compared to weight gain due to increased body fat, can be effective in reducing the cold tolerance because the area from which heat transfer takes place has expanded. On the other hand, subcutaneous fat may reduce the surface temperature of the body because it restricts heat transfer from the body depth to the surface (22-24).

The correlation was further examined by gender. The results showed that the correlation in men was positive and significantly associated with BMI. No significant relationship was observed between body temperature and BMI in women. Lack of correlation in women may be due to the sudden and intense secretion of Luteinizing Hormone (LH) since it can change body temperature to some extent. This process continues until menstruation and is somewhat dependent on pregnancy. Studies have proven that women's temperature during the menstrual cycle changes due to hormonal changes. After ovulation, their body temperature rises 0.6 degrees compared to the first two weeks of menstruation (25). Since this factor was not taken into account in all the studies, it was excluded from the metaanalysis. Two other factors, i.e., lower muscle volume and higher body surface in women, can be somewhat effective in the so-called lack of significance and indicate the fact that women are more sensitive to the cold than men $(26,27)$. 
After evaluating various studies $(11,26,28)$, it was found that the age variable is one of the factors influencing the correlation between BMI and body temperature. It was initially thought that this factor could partially justify the cause of heterogeneity (difference in the effect size) among studies. Accordingly, the age variable was analyzed as a moderator variable. The results showed that an increase in the age variable reduces the effect size logarithm. According to the slope presented in Table 3, there was a logical relationship between these variables as the age variable could account for $43 \%$ of changes in variance (the difference between studies). Waalen et al. demonstrated that age has a negative effect on body temperature (11). In contrast, Vollenweider et al. revealed a positive relationship between age and body temperature (26). Research has shown that in both men and women, the temperature decreases with age. In women, the results can be enhanced by the onset of menopause (28). Various studies have assessed the relationship between BMI and age, which established that physical activity decreases with an increase in age. Also, the inability in controlling food intake and lack of exercise may increase BMI. Some studies have manifested that mood disorders occur on a daily, monthly, and even seasonal basis in higher ages and pave the way for eating foods rich in carbohydrate, which subsequently increases the BMI. In such situations, an individual resists physical activity, which results in increased obesity (29-31). One of the reasons for the increase in BMI at a higher age in women is possibly the hormonal effects of menopause, which affects not only body temperature but also BMI indices through physiological changes $(29,32)$.

The present study has several limitations. Some of the studies had a small sample size and did not represent all the individuals in their population. As in meta-analyses, body temperature was measured using a variety of methods. These methods included temperature sensor capsule, oral temperature, and tympanic temperature. Unlike tympanic temperature, which is a non-invasive method, in studies that used sensor devices to measure core body temperature, the participants' contribution was relatively low since these pill-sized devices entered the 'patient's stomach and intestines. Therefore, such studies, because of their invasive nature, face difficulties in selecting a large (appropriate and sufficient) sample size. Another limitation of meta-analysis is the lack of inclusion of some variables, which can be attributed to the lack of similarity among studies. For example, some studies did not classify women as premenopausal and post-menopausal, which prevented the effects of menstruation from entering the analyses. Factors such as paracetamol, nonsteroidal anti-inflammatory drugs, and corticosteroids were studied in only one study, so the meta-analyst was restricted in analysing the so-called relationships.

\section{Conclusions}

In this study, body temperature was found in correlation with BMI in the male population. Lack of correlation in women may be due to the sudden and intense secretion of LH because this factor can change the body temperature to some extent. Due to the dissimilarities between studies in evaluating the effective variables, further studies are recommended to assess more and similar variables such as menstruation and the effect of different drugs, which could assist the researchers in examining the studies based on further evidence and similarities.

\section{Acknowledgments:}

The authors declare that the current study was not financially supported by any institution or organization. The authors acknowledge the immense help received from the scholars whose articles are cited and included in the reference of this manuscript. The authors are also grateful to the authors /editors/publishers of all those articles, journals, and books from which the literature for this article has been reviewed and discussed.

\section{Conflict of Interest:}

There is no conflict of interest to be declared.

Authors' contributions:

All authors contributed to this project and article equally. All authors read and approved the final manuscript.

\section{References:}

1) Followay BN, Vaughan JA, Arroyo E, et al. Effects of Environmental Condition and Body Fat Percentage on Substrate Utilization during and following Exercise: 1050: Board\# 284 May 29 2: 00 PM-3: 30 PM. Med Sci Sports Exerc. 2019;51(6):279. doi: 10.1249/01.mss.0000561340.73983.35

2) te Kulve M, Schlangen L, Schellen L, et al. Correlated colour temperature of morning light influences alertness and body temperature. PHYSIOL BEHAV. 2018;185:1-13. doi: 10.1016/j.physbeh.2017.12.004, PMid: 29223712 
3) Schmidt M, Komagata N, Latifi B. 0064 Lateral Hypothalamic Control of REM Sleep Expression During Ambient Temperature Warming. Sleep. 2018;41:A26. doi: 10.1093/sleep/zsy061.063

4) Tan CL, Knight ZA. Regulation of body temperature by the nervous system. Neuron. 2018;98(1):31-48. doi: 10.1016/j.neuron.2018.02.022, PMid: 29621489, PMCid: PMC6034117

5) Chudecka M, Lubkowska A, Kempinska-Podhorodecka A. Body surface temperature distribution in relation to body composition in obese women. Journal of thermal biology. 2014 Jul;43:1-6. PubMed PMID: 24956951. Epub 2014/06/25. eng. doi: 10.1016/j.jtherbio.2014.03.001

6) Prentice AM, Black A, Coward W, et al. High levels of energy expenditure in obese women. Br Med J (Clin Res Ed). 1986;292(6526):983-7. doi: 10.1136/bmj.292.6526.983 PMid: 3083978, PMCid: PMC1339917

7) Berger RJ, Phillips NH. Comparative aspects of energy metabolism, body temperature and sleep. Acta Physiol Scand Suppl. 1988;574: 21-7. PubMed PMID: 3072836. Epub 1988/01/01. eng.

8) Garami A, Székely M. Body temperature: Its regulation in framework of energy balance. Temperature (Austin) [Internet]. 2014 Apr-Jun; 1(1):28-9. doi: 10.4161/temp.29060, PMid: 27583277, PMCid: PMC4972507

9) Eriksson H, Svardsudd K, Larsson B, et al. Body temperature in general population samples. The study of men born in 1913 and 1923. Acta Med Scand. 1985;217(4):347-52. PubMed PMID: 4013825. Epub 1985/01/01. eng. doi: 10.1111/j.0954-6820.1985.tb02708.x

10) Hoffmann ME, Rodriguez SM, Zeiss DM, et al. 24-h core temperature in obese and lean men and women. Obesity (Silver Spring, Md). 2012 Aug;20(8):1585-90. PubMed PMID: 22240727. Epub 2012/01/14. eng. doi: 10.1038/oby.2011.380

11) Waalen J, Buxbaum JN. Is older colder or colder older? The association of age with body temperature in 18,630 individuals. J Gerontol A Biol Sci. 2011;66(5):487-92. doi: 10.1093/gerona/glr001, PMid: 21324956, PMCid: PMC3107024

12) Heikens MJ, Gorbach AM, Eden HS, et al. Core body temperature in obesity. Am J Clin Nutr. 2011;93(5):963-7. doi: 10.3945/ajcn.110.006270, PMid: 21367952, PMCid: PMC3076651

13) Rising R, Keys A, Ravussin E, et al. Concomitant interindividual variation in body temperature and metabolic rate. American Journal of Physiology-Endocrinology and Metabolism. 1992;263(4):E730-E734. doi: 10.1152/ajpendo.1992.263.4.E730, PMid: 1415692

14) Adam K. Human body temperature is inversely correlated with body mass. Eur J Appl Physiol Occup Physiol. 1989 1989/03/01;58(5):471-5. doi: 10.1007/BF02330699, PMid: 2759072

15) Basu R, Feng W-Y, Ostro BD. Characterizing temperature and mortality in nine California counties. Epidemiol. 2008:138-45. doi: 10.1097/EDE.0b013e31815c1da7, PMid: 18091422

16) Barnett AG, Tong S, Clements AC. What measure of temperature is the best predictor of mortality? Environ Res. 2010;110(6):604-11. doi: 10.1016/j.envres.2010.05.006, PMid: 20519131

17) Hajat S, Kosatky T. Heat-related mortality: a review and exploration of heterogeneity. J EPIDEMIOL COMMUN H. 2010;64(9):753-60. doi: 10.1136/jech.2009.087999, PMid: 19692725

18) Moher D, Liberati A, Tetzlaff J, et al. Preferred reporting items for systematic reviews and meta-analyses: the PRISMA statement. Annals of internal medicine. 2009;151(4):264-9. doi: 10.7326/0003-4819-151-4200908180-00135, PMid: 19622511

19) Wells G, Parkash R, Healey JS, et al. Cardiac resynchronization therapy: a meta-analysis of randomized controlled trials. Cmaj. 2011;183(4):421-9. doi: 10.1503/cmaj.101685, PMid: 21282316, PMCid: PMC3050946

20) Pieters N, Plusquin M, Cox B, et al. An epidemiological appraisal of the association between heart rate variability and particulate air pollution: a meta-analysis. Heart. 2012;98(15):1127-35. doi: 10.1136/heartjnl2011-301505, PMid: 22628541, PMCid: PMC3392690

21) Borenstein M, Hedges LV, Higgins JP, et al. Introduction to meta-analysis: John Wiley \& Sons; 2011.

22) Saedpanah K, Aliabadi M, Motamedzade M, et al. Study of Exposure to Cold Stress and Physiological Responses in Auto Mechanics in Hamadan, Iran. J OCCUP ENVIRON HYG. 2017;4(2):7-17. doi: 10.21859/johe.4.2.7

23) Pretorius T, Lix L, Giesbrecht G. Shivering heat production and body fat protect the core from cooling during body immersion, but not during head submersion: A structural equation model. Comput Biol Med. 2011;41(3):154-8. doi: 10.1016/j.compbiomed.2011.01.005, PMid: 21295291

24) O'Brien C, Castellani JW, Sawka MN. Thermal face protection delays finger cooling and improves thermal comfort during cold air exposure. Eur J Appl Physiol. 2011;111(12):3097-3105. doi: 10.1007/s00421-0111931-2, PMid: 21461929 
25) Fehring RJ, Schneider M, Raviele K. Variability in the phases of the menstrual cycle. Journal of obstetric, gynecologic, and neonatal nursing : JOGNN. 2006 May-Jun;35(3):376-384. PubMed PMID: 16700687. Epub 2006/05/17. eng. doi: 10.1111/j.1552-6909.2006.00051.x

26) Bastardot F, Marques-Vidal P, Vollenweider P. Association of body temperature with obesity. The CoLaus study. Int J Obes. 2019;43(5):1026-33. doi: 10.1038/s41366-018-0218-7, PMid: 30250242, PMCid: PMC6760582

27) Neff LM, Hoffmann ME, Zeiss DM, et al. Core body temperature is lower in postmenopausal women than premenopausal women: potential implications for energy metabolism and midlife weight gain. Cardiovasc Endocrinol. 2016;5(4):151. doi: 10.1097/XCE.0000000000000078, PMid: 28111609, PMCid: PMC5242227

28) Ruggiero G, Rapuano M, Iachini T. Perceived temperature modulates peripersonal and interpersonal spaces differently in men and women. J Environ Psychol. 2019;63:52-9. doi: 10.1016/j.jenvp.2019.04.004

29) Moshirian Farahi SM. The Relationship between Body Mass Index, Depression and Age in Individuals Referring to the Health Center in Norabad Delfan City in 2013. J Ilam Uni Med Sci. 2014;22(1):130-8.

30) Ng TP, Jin A, Chow KY, et al. Age-dependent relationships between body mass index and mortality: Singapore longitudinal ageing study. PLoS One. 2017;12(7). doi: 10.1371/journal.pone.0180818, PMid: 28738068, PMCid: PMC5524359

31) Reas DL, Nygård JF, Svensson E, et al. Changes in body mass index by age, gender, and socio-economic status among a cohort of Norwegian men and women (1990-2001). BMC Public Health. 2007;7(1):269. doi: 10.1186/1471-2458-7-269, PMid: 17903273, PMCid: PMC2222164

32) Öner N, Sari A, Ekuklu G, et al. Prevalence of underweight, overweight and obesity in Turkish adolescents. Swiss Med Wkly. 2004;134(3536). 